\title{
Ürdün Üniversitesi Kütüphanesi’nde Bulunan Osmanlı ve Türkiye ile Alakalı Tezler
}

Yasin BEYAZ1

\author{
$\ddot{\mathbf{O} z}$
}

\begin{abstract}
Biz bu makalede Ürdün Üniversitesi Kütüphanesi'nde yer alan Osmanlı ve Türkiye ile alakalı tezleri konularına göre tasnif ederek araştırmacıların ilgisine sunduk. Böylelikle Birinci Dünya Savaşı ve Büyük Arap İsyanı sonrasında dağılan Osmanlı Devleti ve yeni kurulan Türkiye Cumhuriyeti’nin Arap akademisyenlerin tezlerine ne şekilde konu olduğunu göstermek istedik. Söz konusu tezlerin her ne kadar isimleri verilmiş olsa da konu ile alakalı araştırma yapan akademisyenlere belli bir fikir vereceğini ümit ediyoruz.
\end{abstract}

Anahtar Kelimeler: Ürdün, Osmanlı, Türkiye, Arapça, tez, siyaset, tarih.

\section{The Dissertations on The Ottomans And Turkey in The Library of Jordan University}

\begin{abstract}
In this article, we have organized the theses related to Ottoman Empire and Turkey in the Library of Jordan University according to their subjects and offered them to interested researchers. Thus, we wanted to show how the Ottoman Empire, dispersed after the First World War and the Great Arab Revolt, and the newly founded Republic of Turkey, were addressed in theses of Arab scholars. Though the information given is limited in relation to theses, we hope to give a certain opinion to academicians who are engaged in research related to the subject.
\end{abstract}

Key words: Jordan, Ottoman, Turkey, thesis, politics, history.

\section{Giriş}

Birinci Dünya Savaşı'ndan sonra Osmanlı İmparatorluğu dağılınca Türkler ve Arapların yolları (özellikle siyasi olarak) birbirinden ayrılmıştır. Aradan geçen bir asırlık döneme baktığımız zaman çeşitli yakınlaşmalar olsa da 2000'li yıllara kadar Türkiye-Arap Dünyası ilişkisi hep inişli çıkışlı olmuştur. 1955 yılında imzalanan Bağdat Paktı ile Menderes’in başlattığı Ortadoğu'ya açılma girişimi ve benzeri bazı hamleler Soğuk Savaş (veya başka siyasi olaylar) nedeniyle ortaya çıan kutuplaşmadan dolayı olumlu sonuç vermemiştir. 200o'li yıllardan sonra Türkiye'nin yüzünü tekrardan ve daha ısrarlı bir şekilde Arap coğrafyasına çevirmesi üzerine akademik camia da buna kayıtsız kalmamıştır. Yirminci yüzyılın ikinci yarısından itibaren Osmanlı ve Türkiye ile alakalı akademik çalışmalar yapılmaya başlanmıştır ancak yirmi birinci yüzylla beraber bu çalışmalarda ciddi bir artış gözlenmiştir.

Türkiye ile alakalı olarak yapılan tezler çeşitlilik göstermiş olmasına rağmen akademik çalışmaların daha çok siyasi ve tarihi konulara yoğunlaştığını söyleyebiliriz. Türk siyasetiyle ilgili tezler Türkiye'nin dış siyasetini incelediği gibi iç siyasi dinamikleri de göz ardı etmez. Tarihi tezler ise daha çok Biladü’şŞam, Yemen, Hicaz gibi bölgelerin Osmanlı dönemi tarihleri ve bunların Osmanlı ile olan ilişkileri

Dr. Öğr. Üyesi, Yalova Üniversitesi, İslami İlimler Fakültesi, Türk İslam Edebiyatı Bölümü, yasinbeyaz8o@hotmail.com [Makale kayit tarihi: 18.2.2018-kabul tarihi: 14.4.2018] 
üzerinde durmaktadır. Bu ilişkileri siyasi tarih haricinde toplumsal ve iktisadi yönlerden de ele alan çalışmalar mevcuttur.

\section{Ürdün Üniversitesi Kütüphanesi}

Ürdün Üniversitesi 2 Eylül 1962 yılında çıkarılan bir kararla kurulmuş olup aynı yıl Ürdün Üniversitesi Kütüphanesi de faaliyetine başlamıştır. Çok geniş bir alana kurulan kütüphane öğrenci ve araştırmacıların hizmetine sunulmuştur. Üç daire ve dokuz şubeden oluşan idari bir yapıya sahiptir. Başta öğrenciler olmak üzere günde ortalama 11.000 yerli ve yabancı araştırmacı tarafından kullanılmaktadır. Ürdün Üniversitesi Kütüphanesi’ni önemli kılan özelliklerinden birisi içerisinde Tez Toplama Merkezi barındırıyor olmasıdır. 1986 yılından itibaren Arap Üniversiteleri Birliği’ne üye olan Ürdün Üniversitesi, birliğe bağlı bulunan bütün üniversitelerin tezlerini kendi kütüphanesinde barındırmaktadır. Bu nedenle kütüphanenin Tez Bölümü'nde toplam 53.00o tez mevcut olup bunların 47.00o adedi elektronik ortamda okuyucu ve araştırmacıların hizmetine sunulmuştur. ${ }^{2}$

Üniversite Kütüphanesi’nin Arşiv Bölümü’nde ise Arapça elyazması kitaplar, belgeler, Arapça gazete ve dergilerin yanında bunların mikrofilmleri mevcuttur. Toplam 235.00o (iki yüz otuz beş bin) sayı gazete ve 6.000.00o (altı milyon) sayfa Arapça, İngilizce ve Fransızca belge bulunmaktadır. 3 Üç katlı olan Ürdün Üniversitesi Kütüphanesi’nin "Bodrum Katı”nda dergi, arşiv, fotokopi, kitap ciltleme ve kitap tamiri bölümleri yer almaktadır. "Giriş Kat” ta kütüphane yönetimi, tez bölümü ve öğrenciler için çalışma mekânları mevcuttur. "Birinci Kat”ta matbu kitap bölümü, ödünç verme servisi, bilgisayardan kitap tarama bölümü, Kudüs Kitaplı̆̆ı, Haşimi Koleksiyonu ve Özel Koleksiyon vardır. İkinci katta ise öğrenciler ve araştırmacıların çalışacağı mekânlar bulunmaktadır. 2006 yllından itibaren bilgisayar sistemine geçen kütüphanede artık araştırmacılar bilgisayar üzerinden tarama yapabilmektedir. Ayrıca kütüphane Pazar-Perşembe günleri 08.00-24.00 ve Cumartesi 09.00-19.00 saatleri arasında okuyucu ve araştırmacıların hizmetine açıktır. Kütüphanede açık raf sistemi uygulanmaktadır.

\section{Ürdün Üniversitesindeki Osmanlı ve Türkiye ile Alakalı Tezler}

Ürdün Üniversitesi Kütüphanesi Tezler Bölümü’nde yer alan Osmanlı ve Türkiye ile alakalı tezlerin büyük bir kısmı yüksek lisans tezleridir. Bu tezler tarih, siyaset, mimari ve edebiyat üzerine yazılmıştır. Bunlardan bir tanesi İngilizce olup diğerlerinin tamamı Arapçadır. Ürdün Üniversitesi Kütüphanesi’nde bulunan Osmanlı ve Türkiye ile alakalı tezlerin yapıldığı ülkeler, üniversiteler ve yapılan tez adetlerini şöyle siralayabiliriz: Cezayir 6 (Cezayir Üniversitesi), Filistin 6 (en-Necahü’l-Vataniyye 3, Kudüs Üniversitesi 3), Lübnan 10 (Beyrut el-Arabiyye 2, Kaddis Yusuf 4, Lübnan 3, İslamiyye Üniversitesi 1), Irak 9 (Basra 1, Musul 6, Mustansıriyye Üniversitesi 2), Libya 1 (Karbons/Bingazi Üniversitesi 1), Mısır 4 (Aynu'ş-Şems Üniversitesi 4), Sudan 1 (Ümmü Derman el-İslamiyye Üniversitesi 1), Suriye 41 (Dimeşk 32, Halep 7, El-Baas 1, Teşrin Üniversitesi 1), Suudi Arabistan 2 (Ümmü’l-Kura Üniversitesi), Ürdün 47 (Al-i Beyt 1, Şarku'l-Evsat 3, Yermûk 9, Ulumü'l-İslamiyyetü'l-Alemiyye 1, Ürdün Üniversitesi 23) ve Yemen 3 (Sana Üniversitesi).

Türklerle alakalı tezlerin tamamı 130 adet olup en fazla tezin yapıldığı üniversite Dimeşk Üniversitesi'dir. Tezlerin büyük bir kısmına dair genel bilgiler yer almasına rağmen bazılarının sadece tez ve hazırlayanlarının isimleri mevcuttur.

\footnotetext{
2 Library of Jordan University. 13.08.20017, http://library.ju.edu.jo/EN-library/AboutLibrary.aspx. H. Ermiş, Ürdün Üniversitesi Kütüphanesinde Bulunan Arap Dili ve Edebiyatı Tezleri. Sakarya Üniversitesi İlahiyat Fakültesi Dergisi, (19), s. 219-220.
} 
İncelemiş olduğumuz tezlerin tasniflerini konularına göre yaptık. Üniversite kütüphanesinde bulunan tezlerin künyelerini verirken şu sıralamaya riayet ettik: 1-Tezin orijinal ismi (Arapça), 2-Tezin isminin Türkçe çevirisi, 3- Tezi hazırlayanın ismi, 4- Tez Danışmanı, 5- Tezin Yapıldığı Üniversitenin Adı, 6Yüksek lisans mı yoksa doktora tezi mi olduğu, 7- Tezin hazırlandığı bölüm, 8- Tezin hazırlandığı yıl, 9Tezin yer numarası.

Siyaset ile Alakalı Tezler: Siyaset ile alakalı tezlere baktığımızda hazırlanan tezlerin tamamına yakınının iki binli yıllardan sonra olduğunu görmekteyiz. Bu tezlerden bazıları Türkiye’nin iç siyaseti dinamiklerini ele alırken diğerleri Türkiye-İsrail ve Türkiye-Ortadoğu Devletlerinin (Ürdün, Irak, Suriye) ilişkilerini incelemektedir. Yapılan bu akademik çalışmalarda Türkiye'nin AB üyeliği meselesi, Türkiye'nin İsrail ile ilişkileri, Frrat Suyu'nun Türk Arap ilişkilerine tesirleri ve Ak Parti’nin Ortadoğu siyasi gibi konular Türk-Arap ilişkilerinin ana unsuru olarak karşımıza çıkmaktadır. Bu çalışmaların dikkatimizi çeken başka bir özelliği ise Ürdün Üniversitesi’nde yapılan tezlerin merkezini Türkiye-İsrail ilişkileri ve Türkiye’nin Ortadoğu'ya yönelme sebepleri oluşturmaktadır.

1-1779-1600) الصراع الفارسي - العثماني وأثره في الخليج العربي (Osmanll-Fars Mücadelesi ve Bunun Haliç Araplarına Tesiri 1600-1779) Hazırlayan: Alaaddin Fevzî Cebbûr, Danışman: Dr. Ahmed el-Haddâr, Dimeşk Üniversitesi, Yüksek Lisans Tezi, Yakın Çağ ve Çağdaş Arap Tarihi, 2013, Yer Numarası: 955.03

2-1973-1946-19ürkiye ve Suriye’nin Siyâsî İlişkileri 1946-1973) Hazırlayan: Şâdî Mustafa, Danışman: Prof. Dr. Semir Behlivan, Dimeşk Üniversitesi, Yakın Çağ ve Çağdaş Arap Tarihi, 2010, Yer Numarası: 956.01

3-1958-1946) أثر السياسة الدولية على العلاقت السوريةـ التركية (Uluslararası Siyasetin Türkiye-Suriye İlişkilerine Tesiri 1946-1958) Hazırlayan: Sabâh Sâlih Rızâ, Danışman: Prof. Dr. Muhammed Ahmed-Prof. Dr. Muhammed Yûfâ, Dimeşk Üniversitesi, Yüksek Lisans Tezi, Yakın Çağ ve Çağdaş Arap Tarihi, Yer Numarasi: 327.561053

4- الدور السياسي للقوميات في تركيا: الأكر اد (Milliyetçiliğin Türk Siyasetindeki Rolü: Kürtler) Hazırlayan: Ahmed Abdulbâkî Ahmed, Danışman: Dr. Münir Abdulmecid el-Bedrî, Mustansıriyye Üniversitesi, Yüksek Lisans Tezi, 1989, Yer Numarası: 322.40953

5-1958-1926 (Türkiye ve Irak Arasındaki Ticârî İlişkiler 1926-1958) Hazırlayan: Ali Hamza es-Sûfî, Danışman: Dr. Züheyr Ali Nühhâs, Yer Numarası: 956.302

6- موقف تركيا من الصراع العربي_الإسرائيلي في حقبة ما بعد الحرب الباردة (Soğuk Savaş Sonrası Dönemde Arap-İsrail Sorununda Türkiye’nin Tutumu), Hazırlayan: Kemîl Abdurrazî Sâlih, Danışman: Dr. Kâmil Habîb, 2004, Yer Numaras1: 327.53

7- Rediscovering Geopolitics: Assesing The Shift in Turkish Foreign Policy Southwards Since The Arrival of Erdogan's Administration to Power (Jeopolitiğin Yeniden Keşfi: Erdoğan Yönetiminin İktidara Gelmesinden Sonra Türkiye'nin Ortadoğu ile Alakalı Değişen Politikasını Değerlendirmek) Hazırlayan: Ğayt Hasan el-Ameyrah, Danışman: Prof. Dr. Velid Ebu Dalbuh, Ürdün Üniversitesi, Yüksek Lisans Tezi, 2013, Yer Numarası: 489327.53

8- الإستراتيجية التركية اتجاه الثرق الأوسط (Türkiye’nin Ortadoğu’ya Yönelişindeki Strateji 19902010) Hazırlayan: Kefâh İsa Mûsa el-Vahş, Danışman: Dr. Faysal er-Rufû, Ürdün Üniversitesi, Yüksek Lisans Tezi, Siyasal Bilimler, Yer Numarası: 327.53056 
9- العلاقات الإسرائلية - التركية في عهد حزب العدالة (AK Parti Döneminde Türkiye-İsrail İlişkileri) Hazırlayan: Muhammed Cemâl Yunus Esad, Danışman: Muhammed Hamdân Musâlaha, Ürdün Üniversitesi, Yüksek Lisans Tezi, Siyasal Bilimler, 2011, Yer Numarası: 327.5305641

10- الدور الإقليمي التركي في الثرق الأوسط بعد الحرب الباردة (Soğuk Savaş’tan Sonra Ortadoğu'da Türkiye'nin Bölgesel Rolü) Hazırlayan: İmâd Abdurrahîm Hıdır ed-Damîr, Danışman: Dr. Ziyâb Muhadime, Ürdün Üniversitesi, Yüksek Lisans Tezi, Siyasal Bilimler, 2001, Yer Numarası: 327.53056

11- العلاقات الإسرائيليةـ التركية بعد أزمة الخليج الثانية (İkinci Haliç Krizinden Sonra Türkiye-İsrail İlişkileri) Hazırlayan: Emced Abdullah Sâlih Kavâsıme, Danışman: Dr. Muhammed Fıdda, Ürdün Üniversitesi, Yüksek Lisans Tezi, 2001, Yer Numarası: 327.564053

12- توجهات السياسة التركية الخارجية التركية تجاه العالم العربي (Türk Dış Siyasetinin Arap Dünyasına Yönelimi) Hazırlayan: Kifâye Hudeydûn, Danışman: Dr. Abdulkadir Fehmi et-Tâî, Ürdün Üniversitesi, Yüksek Lisans Tezi, Siyasal Bilimler, 2012, Yer Numarası: 327.53056

13-1958-1946) العلاقات الأردنية - التركية في الفترة مابين عامي(Ürdün-Türkiye İlişkileri 1946-1958) Hazırlayan: Bera Salâh Abdulhamid Gitâşa, Danışman: Dr. Abdulmecîd Şenâg, Ürdün Üniversitesi, Yüksek Lisans Tezi, Tarih, 2012, Yer Numaras1: 327.565053

14- دور المؤسسة العكرية في السياسة الخارجية التركية (Türk Dış Siyasetinde Askerî Müeessesenin Rolü) Hazırlayan: Luî Ahmed Avcî, Danışman: Dr. Abdullah Nakraş, Ürdün Üniversitesi, Yüksek Lisans Tezi, Siyasal Bilimler, Yer Numarasi: 327.53

15- العلاقات العر اقية - التركية (Türkiye-Irak İlişkileri 1991-2000) Hazırlayan: Muhammed Salâh Muhammed el-Kebâbcî, Danışman: Dr. Muhammed İbrahim Fıdda, Ürdün Üniversitesi, Yüksek Lisans Tezi, Siyasal Bilimler, 2002, Yer Numarası: 327.563053

انضمام تركيا إلى الإتحاد الأوروبي وأثره في الأمن القومي العربي -16 (Türkiye'nin Avrupa Birliği’ne Dahil Olması ve Bunun Arapların Güvenliğine Tesiri) Hazırlayan: Muhammed el-Arabî Uveyyid Marazî, Danışman: Prof. Dr. Kemâl Hammâd, Beyrut el-Arabiya Üniversitesi, Yüksek Lisans Tezi, Devletlerarası İlişkiler ve Diplomasi, 2008, Yer Numarası: 327.5304

17-(1960-1946) التطورات السياسية الداخلية في تركيا (Türkiye'deki İç Siyâsî Gelişmeler 1946-1960) Hazrrlayan: Muhsin Hamza Hasan el-Abîdî, Danışman: Dr. Abdulcebbâr Kâdir Gafûr, Musul Üniversitesi, Yüksek Lisans Tezi, Yakın Çă̆, 1989, Yer Numarası: 953.03

18-1939-1936) العلاقات البريطانية - التركية (Türkiye-Britanya İlişkileri 1936-1939) Hazırlayan: Hanâ Uzv Behnân, Danışman: Dr. Halil Ali Murad, Yer Numarası: 941.084

19- مشروع جنوب شرقي الأناضول ونأثيره في العلاقات العربية - التركية (Güney Doğu Anadolu Projesi ve Türk-Arap İlişkisine Etkileri) Hazırlayan: Riyâd Zünûn Muhammed Hasan Abbâsî, Danışman: Dr. Halil Ali Murad, Musul Üniversitesi, Doktora Tezi, Yakın Çă̆ Tarihi, 2004, Yer Numarası: 953.03

20-2009-2001 العلاقات التركيةـ الإسر ائيلية في ضوء الإستراتيجية التركية (Türkiye’nin Stratejisi Işığında Türk-İsrail İlişkileri 2001-2009) Hazırlayan: Abdulkerîm Kâzım Acîl, Danışman: Dr. Emîn, Hatît, İslâmiyye Üniversitesi, Yüksek Lisans Tezi, Siyasal Bilimler, Yer Numarası: 327.5305641 
21- الإسلام السياسي : حزب العدالة والتتمية في تركيا ودوره في التغيير السياسي (Siyasal İslâm: Adalet ve Kalkınma Partisi ve Onun Döneminde Değisşen Siyaset) Hazırlayan: Revâ Câsim Latîf es-Saidî, Danışman: Prof. Dr. Muhammed Avd el-Huzeyme, Şarku'l-Evsât Üniversitesi, Yüksek Lisans Tezi, Siyasal Bilimler, 2010, Yer Numarasi: 210.4324253

22-2008-1990 العلاقات التركية الإير انية من العام (Türkiye ve İran İlişkileri 1990-2008) Hazırlayan: Raad Habîb Mustafa, Danışman: Dr. Muhammed el-Kıtâtşa, Mute Üniversitesi, Yüksek Lisans Tezi, Siyasal Bilimler, 2010, Yer Numaras1: 327.53055

23- مياه الفرات والعلاقات العربيةـ التركية (Furat Suyu ve Arap-Türk İlişkileri 1983-1995) Hazırlayan: Sâmir Sadî Miskâl Câbir, Danışman: Dr. Ahmed Muhammed Reşîî, Âl-i Beyt Üniversitesi, Yüksek Lisans Tezi, Yüksek Lisans Tezi, Siyasal Bilimler, 1997, Yer Numarası: 333.9100956

24- اتفاقيات التجارة الثنائية و أثرها على التجارة الخارجية السورية(دراسة خاصة.الاتفاقية الثنائية السوريةـ التركية) (Suriye’nin İkili Ticârî İttifakları ve Bunların Suriye'nin Dış Ticâretine Etkileri: Türkiye-Suriye İkili İlişkileri Özelinde Bir İnceleme) Hazırlayan: Nîfîn Mustafa el-Bûz, Danışman: Dr. Selmân Nasr Osman, Teşrîn Üniversitesi, Yüksek Lisans Tezi, İktisat, Yer Numarası: 337.561053

المؤسسة العسكرية و السياسية العامة في تركيا:دراسة في جدليات المجتمع وسياسة الدولة الخارجية-25 (Türkiye'de Siyâsî ve Askerî Müesseseler: Toplumsal Mücadeleler ve Devletin Dış Politikası) Hazırlayan: Âkil Mahfuz, Danışman: Dr. Samir İsmail-Dr. Amir Lütfî, Halep Üniversitesi, Doktora Tezi, 2006, Devletler Arası İlişkiler, Yer Numarası: 320.953 .

26- العلاقات التركية _الإسرائلية وانعكاساتها على المنطقة العربية (Türkiye-İsrail İlişkileri ve Bunun Arap Dünyasına Yansıması) Hazırlayan: Avnî el-Hımsî, Danışman: Dr. Amir Lütfî-Dr. İsmail Şaban, Halep Üniversitesi, Yüksek Lisans Tezi, Devletler Arası İlişkiler, Yer Numarası: 327.5305641.

Tarih ile Alakalı Tezler: Bu başlık altındaki tezler Arap beldelerinin Osmanlı idaresi altındaki tarihlerini ele almaktadır. Yemen, Biladü'ş-Şam (Ürdün, Suriye, Filistin), Irak, Hicaz, Lübnan, Cezayir gibi ülkelerin siyasi, sosyal, iktisadi ve ictimai tarihlerini incelemekle beraber Osmanlı devletindeki ıslahatların buralara yansımaları da bu çalışmalarda ele alınan konular arasındadır.

Bununla birlikte bu beldelerde yer alan yerel güçlerin Osmanlı merkez idaresi ile olan ilişkisi de tezlerin diğer bir mevzusudur. Bunların yanında İttihat ve Terakki yönetimi ve Arap isyanı dikkati çeken diğer bir konudur.

1-1635-1538) الوجود العثماني في اليمن(Osmanlı'nın Yemen'de Mevcûdiyetî 1538-1635) Hazırlayan: Muhsin Muhammed Âyid Ali ed-Derbî, Danışman: Dr. Abdulmenam El-Ahmed, Dimeşk Üniversitesi, Tarih Bölümü, 2010-2011, Yer Numarası: 956.082

2) (17. ve 18. Yüzyllarda Mısır ve Biladü'ş-Şâm'da Osmanlı Hakimiyetine Muarız Dikkat Çeken Mahallî İsyanlar: Bir Tahlîl) Hazırlayan: Esber Ali, Danışman: Prof. Dr. Mahmûd Ammâr, Dimeşk Üniversitesi, Doktora Tezi, Yakın Çağ ve Çağdaş Arap Tarihi, 2008, Yer Numarası: 956.082

3-3 الحباة الاجتماعية والفكرية في الدولة العثمانية (Osmanlı'da İctimâî ve Fikrî Hayat 1808-1909) Hazırlayan: Ali Muhammed İbrahim, Danışman: Mahmûd Ali Ammâr, Dimeşk Üniversitesi, Tarih Bölümü, 2010-2011, Yer Numarası: 956.082 


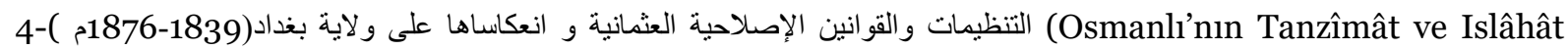
Kânûnları ve Bunların Bağdat Vilâyetine Yansıması 1839-1876) Hazırlayan: İyâd Hamâdî Sellâc, Danışman: Prof. Dr. Mahmûd Ali Âmir, Dimeşk Üniversitesi, Yüksek Lisans Tezi, Yakın Çağ ve Çağdaş Arap Tarihi, 2011, Yer Numarası: 956.082

5- الإدارة العثمانية في ولاية دمشق(STam Vilâyetinde Osmanlı İdaresi 1873-1917) Hazırlayan: Kemâl Esad Abdo, Danışman: Prof. Dr. Mahmûd Ali Âmir, Dimeşk Üniversitesi, Yüksek Lisans Tezi, Yakın Çă̆ ve Çağdaş Arap Tarihi, 2007, Yer Numarası: 956.082

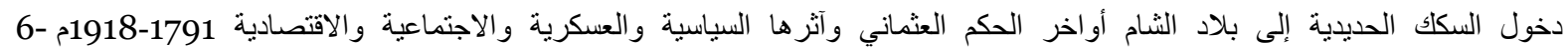
(Osmanlı'nın Son Dönemlerinde Demiryollarının Bilâdü’ş-Şâm'a Girişi ve Bunların Siyâsî, Askerî, İctimâî ve İktisâdî Etkileri 1791-1918) Hazırlayan: İzzet Ali Akbıyık, Danışman: Prof. Dr. Semir Behlivan, Dimeşk Üniversitesi, Yüksek Lisans Tezi, Yakın Çağ ve Çağdaş Arap Tarihi, 2005-2006, Yer Numarası: 956.081

7- القضاء في ولاية حلب خلال العهد العثماني (Osmanlı Döneminde Halep Vilâyetinde Kadılık 1789-1876) Hazırlayan: Es'ad ‘Abdû, Danışman: Prof. Dr. Mahmûd Âmir, Dimeşk Üniversitesi, Doktora Tezi, Yakın Çağ ve çağdaş Arap Tarihi, Yer Numarası: 956.082

8- (العساكر العثمانية في ولاية حلب(Halep Vilâyetinde Osmanlı Askerleri 1623-1798) Hazırlayan: Sâil Mahmûd Mahlûf, Danışman: Prof. Dr. Semir Behlivan, Dimeşk Üniversitesi, Yüksek Lisans Tezi, Yakın Çă̆ ve Çağdaş Arap Tarihi, Yer Numarası: 956.082

9- فن الحرب لاى الجيثيين العثماني والمصري في بلاد الثشام(Bilâdü’ş-Şam'da Osmanlı ve Misır Ordularının Savaş Stratejileri 1826-1840) Hazırlayan: Câbir Sakr Sultan, Danışman: Prof. Dr. Yusuf Nüeyse, Dimeşk Üniversitesi, Yüksek Lisans Tezi, Yakın Çağ ve Çağdaş Arap Tarihi, 2009, Yer Numarası: 956.082

10-(النقود العثمانية في سوريا (اقتصادية_اجتماعيةسياسية (Suriye'de Osmanlı Parası: İktisâdî-İctimâî-Siyâsî) Hazırlayan: Hikemât Abdurrahman, Danışman: Prof. Dr. Mahmûd Ali 'Ammâr, Dimeşk Üniversitesi, Yüksek Lisans Tezi, Yakın Çağ ve Çağdaş Arap Tarihi, Yer Numarası: 737.49561

11-10smanlı İşgâli Gölgesinde Bilâdü’ş-Şâm'daki İdârî Taksîmâtın Gelişimi 1516-1918) Hazırlayan: Hanân Hüseyin Tikâle, Danışman: Prof. Dr. Semir Behlivan, Dimeşk Üniversitesi, Yüksek Lisans Tezi, Yakın Çağ ve Çağdaş Arap Tarihi, 2006, Yer Numarası: 956.082

12- الإصلاحات في الدولة العثمانية وانعكاساتها على ولاية حلب (Osmanll Devletindeki Islahâtlar ve Bunların Halep Vilayetindeki Akisleri: İktisâdî-İctimâî-Kültürel 1789-1876) Hazırlayan: Hisâm Hasan Süleyman, Danışman: Prof. Mahmûd Ali Âmir, Dimeşk Üniversitesi, Doktora Tezi, Yakın Çă̆ ve Çağdaş Arap Tarihi, 2009, Yer Numarası: 956.082

(Osmanlı Döneminde Cezayir Sikkesi) Hazırlayan: Yemîne Deryâs, Danışman: Dr. Mevlây Bilhamîsî, Cezayir Üniversitesi, 1988, Yer Numarası: 737.4965

14 - الحباة العطلية في اليمن من بداية القرن التاسع الهجري حتى سيطرة العثمانيين عليها (Hicrî 9. Asrın Başından Osmanlı Hakimiyeti Dönemine Kadar Yemen'de Çalışma Hayatı 1392-1538) Hazırlayan: 
Abdulğanî Ali Ğâid el-Emcedî, Danışman: Muhammed İsa Sâbır el-Cerîrî, San'a Üniversitesi, Doktora Tezi, 2008, Yer Numarası: 915.603

15 موقف المؤرخين اليمنيين المعاصرين للحكم العثماني الأول بين مؤيد ومخالف) (Osmanlı’nın İlk Hâkimiyetini Destekleyen ve Ona Muhâlif Olan Yemenli İki Tarihçinin Tutumu) Hazırlayan: Ahmed Sâlih Abdurrabe el-Mısrî, Danışman: Prof. Dr. Seyyid Mustafa Sâlim-Dr. Muhammed Kâsım eş-Şa'bî, San’a Üniversitesi, Yüksek Lisans Tezi, Tarih, 2006, Yer Numarası: 956.082

16-1683-1635/01097-1045م) محاو لات توحيد اليمن بعد خروج العثمانيين الأول (illk Osmanlı Ayrılışından Sonra Yemen’i Birleştirme Çabaları 1635-1683) Hazırlayan: Muhammed Ali es-Sâlimî, Danışman: Dr. Seyyid Mustafa Sâlim, San’a Üniversitesi, Tarih Bölümü, 1988, Yer Numarası: 956.082

17- صدارة آل كوبرولي في العهد العثماني (Osmanlı'da Köprülü Ailesinin Sedâreti) Hazırlayan: Înâs Zekeriyya ElSemâdî, Danışman: Dr. Velîd el-Arîd, Yermûk Üniversitesi, Yüksek Lisans Tezi, Yakın Çağ, 2002, Yer Numarası: 956.08

18- طريق دمثق القس فى العصر العثماني خلال القرنين العاشر والحادي عشر الهجريين /الساد عشر والسابع عثر الميلاديين (Hicrî X. ve XI. /Mîlâdî XVI. ve XVII. Osmanlı Asırları Boyunca Şam-Kudüs Yolu) Hazırlayan: Sâdık Muhammed Tilfâh, Danışman: Dr. Velîd El-Arîz, Yermûk Üniversitesi, Tarih Bölümü, 2002, Yer Numarası: 956.082

19- الطو احين المائية في وادي كفرنجة في العصر المملوكي المتأخر ومستهل العصر لعثماني (Memlûklülerin Son Döneminde ve Osmanlıların Başlangıç Döneminde Vadi Kufrenc'de Su Değirmenleri) Hazırlayan: Muhammed Sadûk Hasan el-Mülkâvî, Danışman: Dr. Sâlih Sârî, Yermûk Üniversitesi, Yüksek Lisans Tezi, Arkeoloji ve Antropoloji Bölümü, 1994, Yer Numarası: 915.6503

الإحسان في دخول مملكة اليمن تحت ظل آل عثمان-20 (Osmanlı İdaresi Altında Yemen'de Osmanlı Hayrâtı) Hazırlayan: Süleyman Yunus Zeydan, Danışman: Prof. Dr. Abdulkerim Ğureyse, Ürdün Üniversitesi, Yüksek Lisans Tezi, Tarih, 1979, Yer Numarası: 956.08

21-1250-1171/0648-567) الممالك الأثرالك في الدولة الأيوبية (Eyyûbî Devletinde Türk Krallıklar 1171-1250) Hazırlayan: Muhammed Mahmûd Ahmed el-Hurûb, Danışman: Prof. Dr. Sâlih Halef Hamârane, Ürdün Üniversitesi, Yüksek Lisans Tezi, Tarih, 1990, Yer Numarası: 956.0551

22- 1876-1914 Yllları Arasında Bilâdü'ş-Şâm'da ArapTürk İlişkileri) Hazırlayan: Muhammed Mâcid es-Seyyid Selâhaddin, Danışman: Dr. Abdulkerîm Ğarâybe, Ürdün Üniversitesi, Tarih, Yer Numarası: 956.082

23- قو انين الدولة العثمانية و صلتها بالمذهب الحنفي (Osmanlı Devleti Kanunları ve Bunların Hanefî Mezhebi İle Bă̆ı) Hazırlayan: Orhan Sâdık Canbolat, Danışman: Dr. Ârif Halîl Ebû Îd, Ürdün Üniversitesi, Doktora Tezi, Flkıh ve Usûlü, 2009, Yer Numarası: 217.4095608

24- النظم النعليمية في مدارس بيت المقس في العصر العثماني (Osmanll Döneminde Beytü’l-Makdis Medreselerinde Eğitim Sistemi) Hazırlayan: Ahmed Abdurrahman Ahmed Vâkid, Danışman: Dr. Abdullah Zâhî Rüşdân, Ürdün Üniversitesi, Yüksek Lisans Tezi, Eğitim Metodu, 1999, Yer Numarası: 317.009564421

25 - حركة التقنين الوضعي و التنظيم القضائي في الدولة العثمانية منذ عهد السلطان سليمان القانوني حتى نهاية الدولة العثمانية (Osmanl1 Devletinde Kânûnî Sultan Süleyman Devrinden Son Döneme Kadar Kadılığın Tanzîmi ve Kanunlaştırma 
Hareketleri) Hazırlayan: Şehâde Saîd es-Süveyirgî, Danışman: Mâcid Ebû Rahiye, Ürdün Üniversitesi, Yüksek Lisans Tezi, Fıkıh ve Teşrîh, 1990, Yer Numarası: 342.5608066

26-28smanlı’nın Son Dönemlerinde Filistin Taşrasında Vergi Sistemi 1771-1837) Hazırlayan: Felle el-Mevlûde Mûsâvî El-Kaşâ̂i, Danışman: Dr. Nasiruddin Saîdûnî, Cezayir Üniversitesi, Yüksek Lisans Tezi, Yakın Çă̆ Tarihi, 1989-1990, Yer Numarasi: 336.200956082

27- ملابس المرأة بمدينة الجزائر في العهد العثماني (Osmanlı Döneminde Cezayirli Kadınların Giysileri) Hazırlayan: Şerife Tayyân, Danışman: Dr. Nâhidüddin Saîdûnî, Cezayir Üniversitesi, Yüksek Lisans, İslâmî Eserler, 1990-1991, Yer Numarası: 391.20965

28- المدافعة الجزائرية في العهذ العثماني (Osmanlı Döneminde Cezayir'de Topçuluk) Hazırlayan: Deryâs Haddar, Danışman: Dr. Mevlây Bilhamîsî, Cezayir Üniversitesi, Tarih Enstitüsü, 1989, Yer Numarası: 358.12096502

29-19o9-1897م موقف الدولة العثمانية من الحركة الصهيونية (Osmanlı'nın Siyonist Harekete Karşı Tutumu 18971909) Hazırlayan: Hasan Ali Hallâk, Danışman: Dr. Ömer Abdulaziz Ömer, Beyrut el-Arabiya Üniversitesi, Yüksek Lisans Tezi, Yakın Çağ Tarihi, 1977, Yer Numarası: 956.08

التعليم المهني في لبنان منذ العهد العثماني حتى اليوم - (Osmanlı'dan Bugüne Lübnan'da Meslekî Eğitim) Hazırlayan: Gâzî Münir Kansu, Danışman: Prof. Dr. Cozef Anton, Kaddîs Yusuf Üniversitesi, Yüksek Lisans Tezi, Eğitim Fakültesi, 1999, Yer Numarası: 373.2409562

31- العلاقات السياسية بين المماليك الجر اكسة و العثمانيين في مصر وبلاد الثام(1517sır ve Bilâdü’ş-Şâm'da Çerkes Beyleri ve Osmanlı Arasındaki Siyasi İlişkiler 1517-1923) Hazırlayan: Hâmid İbrahim Eş-Şeyyâb, Danışman: Prof. Dr. El-Eb Luvis Buzeyye, Kaddîs Yusuf Üniversitesi, Yüksek Lisans Tezi, Tarih, 1990, Yer Numarası: 327.054082

نصييين من الفتح الإسلامي حتى الفتح العثماني(İslâm'ın Fethinden Osmanlı Fethine Nusaybin 649-1516) Hazırlayan: Yunus Naîn Ali Ahmed, Danışman: Dr. C.M. Fîh, Kaddîs Yusuf Üniversitesi, İnsânî İlimler, 1996, Yer Numarası: 956.1

33-1914-1876) كركوك في أواخر العهذ العثماني(Osmanlı'nın Son Dönemlerinde Kerkük 1876-1914) Hazırlayan: Mehdî Sâlih Saîd El-Abbâsî, Danışman: Prof. Dr. İsmet Burhaneddin Abdulkâdir, Musul Üniversitesi, Yüksek Lisans Tezi, Yakın Çă̆ Tarihi, 2005, Yer Numarası: 356.082

(Irak’ta Osmanlı Mali Sistemi 1939-1914) Hazırlayan: Ğânem Muhammed Ali, Danışman: Dr. Halil Ali Murâd, Musul Üniversitesi, Yüksek Lisans Tezi, Yakın Çă̆ Tarihi, 1989, Yer Numarası: 956.082

35-19smanlı Döneminde Hicaz 1876-1918) Hazırlayan: İmâd Abdulaziz Yusuf, Danışman: Prof. Dr. İsmet Burhaneddin Abdulkâdir, Musul Üniversitesi, Yüksek Lisans Tezi, Tarih Bölümü, 2005, Yer Numarası: 856.082

36 قافلة الحج الثامي في شرق الأردن في العها العثماني (Osmanlı Döneminde Ürdün'ün Doğusunda Şamlı Hac Kâfileleri 1516-1918) Hazırlayan: Memûn Aslân benî Yunus, Danışman: Dr. Vecîh Küsrânî, Lübnan Üniversitesi, Yakın Çağ Tarihi, 1998, Yer Numarası: 956.08 
(Yâfâ Kazâsında İdârî, İktisâdî, İctimâî ve İlmî Tarih: Napolyon Bonapart'ın Saldırısından Osmanlı Tanzîmâtına Kadar 1799-1864) Hazırlayan: Abîr Muhammed Katnânî, Danışman: Prof. Dr. Hasan Hallâk, Lübnan Üniversitesi, Yüksek Lisans Tezi, Tarih Bölümü, 2004, Yer Numarası: 956.082

38- الإدارة العثمانية في مدينة طر ابلس الثام1814-1840 (Trablusşâm'da Osmanlı İdaresi 1840-1914) Hazırlayan: Şâdiye Alaaddin, Danışman: Dr. Hasan Hallâk-Dr. Muhammed Ali Kavzî, Lübnan Üniversitesi, Yer Numarası: 956.082

39-19smanlı Devleti'nin Suûdî Ailesine Karşı Tutumu 1891-1914) Hazırlayan: Vedâd Huzeyr Hüseyin eş-Şiteyvî, Danışman: Dr. Muhammed Halîl Câbir, Basra Üniversitesi, Yüksek Lisans Tezi, Yakın Çağ Tarihi, 1989, Yer Numarası: 956.082

40- (Osmanlı Devleti ve İmâm Yahya Arasındaki İlişki 1904-1918) Hazırlayan: Fuad Abdulvahhab Ali eş-Şâmî, Danışman: Hüseyin bin Abdullah elÖmerî, 2009, Yer Numarası: 956.082

41- دور العناصر التركية السياسي والاجتماعي في مصر خلال القرن التاسع عشر (19. Asır Boyunca Türk Unsurların Mısır'da Siyâsî ve İctimâî Rolü) Hazırlayan: Abdulğaffar Mahmûd es-Seyd, Danışman: Dr. Salâh El-Akkâd, 'Aynü’ş-Şems Üniversitesi, Doktora Tezi, Yer Numarası: 962.02

42- قليج علي باثا ودوره في البحرية العثمانية (Kıllı̧ Ali Paşa ve Osmanlı Bahriyesi’ndeki Rolü) Hazırlayan: Muhammed Yusuf, Dr. Saad Ebu'l-Kâsım, 1988, Yer Numarası: 956.082

43-1705-1703 الصراع العثماني مع نقيب الأشر اف القوى المحلية في القسس (Osmanlı’nın Kudüs'teki Yerel Güç Nakîbu'lEşrafla Çatışması 1703-1705) Hazırlayan: Abdulkâdir Mustafa Satîh, Danışman: Dr. Abdulaziz İyâd, Arap Tarihi, Yüksek Lisans Tezi, 2006, Yer Numarası: 956.082

(Kosova'da İslâm’ın Yayllmasında Osmanlının Rolü 1389-1500) Hazırlayan: Sâmir Bayrûş Sâlim Ahmedî, Danışman: Prof. Dr. Abdulkâdir Osman Muhammed Câd er-Râb, Ümmü Derman el-İslâmiyye Üniversitesi, Yüksek Lisans Tezi, İslâm Tarihi, 2006, Yer Numarasi: 949.71013

45-1909-1839-(Osmanlı Dönemi'nde Şam'da Kadılık) Hazırlayan: Emced Muhammed Nuame, Danışman: Dr. Âkil Nümeyr, Dimeşk Üniversitesi, Yüksek Lisans Tezi, 2010-2011, Yakın Çă̆ ve Çağdaş Arap Tarihi, Yer Numarası: 956.082

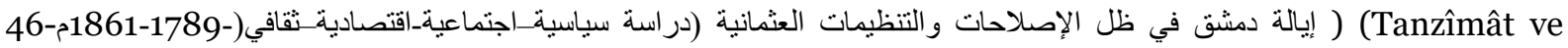
Islâhât Fermanlarının Gölgesinde Şam Eyâleti: Siyâsî-İctimâî-İktisâdî-Kültürel Bakımdan Bir İnceleme 1789-1861) Hazırlayan: Meknun Cuma, Danışman: Prof. Dr. Kâmilyâ Ebu Cebel, Dimeşk Üniversitesi, Yüksek Lisans Tezi, Yakın Çağ ve Çağdaş Arap Tarihi, 2005, Yer Numarası:956.082

47-1916-1831 الهجرات الخارجية من وإلى سورية في العصر العثماني (Osmanlı Döneminde Suriye’ye ve Suriye'nin Dışına Yapılan Göçler 1831-1916) Hazırlayan: Muhammed Abdulhâdî Ulyevî, Danışman: Dr. Yusuf Cemîl Nabeyse, Dimeşk Üniversitesi, Yüksek Lisans Tezi, Yakın Çă̆ ve Çağdaş Arap Tarihi, Yer Numarası: 956.082 
48-1748-1635/1161-1045م) (Yemen’in Osmanll İdaresinden İlk Bağımsızlığı 1635-1748) Hazırlayan: Mustafa Abdulkerîm El-Hatîb, Danışman: Prof. Dr. Yusuf Nüeyse, Dimeşk Üniversitesi, Tarih Bölümü, Yer Numarası: 956.082

49 و لاية بيروت في ظل الإصلاحات العثمانية وتنظيماتها (إداريا- سياسيا - اقتصاديا - اجتماعبا)( 1864-1908) (Tanzîmât ve Islâhât Fermanları Gölgesinde Beyrut Vilayeti: İdârî-Siyâsî-İctimâî-İktisâdî 1864-1908) Hazırlayan: Kinda Küneyhir, Danışman: Prof. Dr. Semir Behlivan, Dimeşk Üniversitesi, Yüksek Lisans Tezi, Yakın Çă̆ ve Çağdaş Arap Tarihi, Yer Numarası: 956.082

50- النظم الإدارية في الدولة العثمانية1507-1520 (Osmanlı'da Yönetim Sistemi 1520-1687) Hazırlayan: Ali Muhammed İbrahim, Danışman: Mahmûd Ali Âmir, Dimeşk Üniversitesi, Yüksek Lisans Tezi, Osmanlı Devleri Tarihi, 2007, Yer Numarası: 956.08

51- التوجهات القومية في صحافة العراق في أواخر الإحتلال العثاني(Osmanlı İşgalinin Son Dönemlerinde Irak Basınında Milliyetçilik Yönelimleri 1908-1914) Hazırlayan: Muhammed Tevfik Hüseyin, Danışman: Dr. Hüseyin Muhammed el-Fehvânî, Mustansıriyye Üniversitesi, Yüksek Lisans Tezi, Sosyalizm ve Milliyetçilik Çalışmaları Bölümü, Yer Numarası: 079.563

52-(Osmanlı Döneminde Yâfâ Kazası 1864-1914) Hazırlayan: Muhammed Sâlim Ğaysân et-Tarâvne, Danışman: Prof. Dr. Ali el-Muhâfaza, Ürdün Üniversitesi, Doktora Tezi, Tarih Bölümü, 1997, Yer Numarası: 956.082

53- سياسة الدولة العثمانية تجاه الخليج العربي(Osmanlı'nın Haliç Bölgesindeki Araplara Karşı Siyaseti 1869-1913) Hazırlayan: Muhammed Abdulkerîm Tevfîk el-Umâyre, Danışman: Prof. Dr. Ali Muhâfaza, Ürdün Üniversitesi, Yüksek Lisans Tezi, Tarih Bölümü, Yer Numarası: 956.082

54- (Osmanlı'nın Son Döneminde Alfahays 1864-1918) Hazırlayan: Mâcide Anton Âyid Diyâd, Danışman: Dr. Mustada Hamârene, Ürdün Üniversitesi, Yüksek Lisans Tezi, Yakın Çă̆ Tarihi, 1996-1997, Yer Numarası: 956.082

55- ناحية جرش في عهذ التنظيمات العثمانية(Osmanlı Tanzîmât’ı Döneminde Ceraş Nâhiyesi 18641918) Hazırlayan: Ahved Abdullah Mahmûd Avde, Danışman: Prof. Dr. Ali Muhâfaza, Ürdün Üniversitesi, Yüksek Lisans Tezi, Yakın Çă̆ Tarihi, 1996, Yer Numarası: 956.082

56- التعليم في العهذ العثماني والامامي الملكي و البريطاني في اليمن إلى الثورة اليمنية (Osmanl, İmam ve İngiltere Hâkimiyetleri Dönemlerinden Yemen Ayaklanmasına Kadar Yemen'de Eğitim) Hazırlayan: Adnân Abduh Nâşir Abdullah, Danışman: Dr. İbrahim Nâsır, Ürdün Üniversitesi, Yüksek Lisans Tezi, Eğitim Fakültesi, 1994, Yer Numarass: 370.35662

57- المر أة الأرمنية في ظل الحكم العثماني (Osmanlı Yönetimi Gölgesinde Ermenî Kadınlar 1878-1923) Hazırlayan: Sonya Kiyork Fânusoğlu, Danışman: Prof. Dr. Muhammed Abdulkâdir Hureysât, Ürdün Üniversitesi, Yüksek Lisans Tezi, Kadın Çalışmaları, 2007, Yer Numarası: 305.4095608

(Osmanlı Yönetimi Zamanında Arap Vilâyetlerinde Köleliğin Durumu 1774-1856) Hazırlayan: Lavrens Nâdir es-Sûsî, Danışman: Dr. Yusuf Cemîl Nueyse, Dimeşk Üniversitesi, Yer Numarası: 956.082 


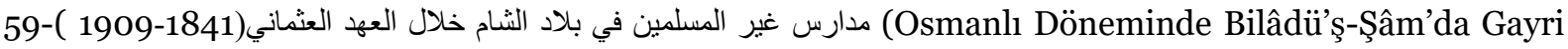
Müslim Okulları 1841-1909) Hazırlayan: Ali Seher Dobâl, Danışman: Dr. Ahmed Abdulmen'am ElAhmed, Dimeşk Üniversitesi, 2013, Yer Numarası: 956.082

60-1908-1876 تطور دمشق الاجتماعى و الاقتصادى و العمرانى فترة السلطان عبد الحميد الثانى (Şam'In II. Abdulhamid Dönemi'nde (1876-1908) Toplumsal, İktisâdî ve Medenî Olarak Gelişim) Hazırlayan: Mari Dikran Serkov, Danışman: Kamilye Ebu Ceyl, Dimeşk Üniversitesi, 2007.

61- تطور عمارة المدارس في مدينة حلب دراسة تحليلية لأهم المدارس حتى نهاية العهد العثماني (Halep’te Okul Binalarmin Gelişimi: Osmanlı'nın Son Dönemine Kadar Önemli Medreseler Üzerine Bir Çözümleme) Hazırlayan: Lemya El-Câsir, Danışman: Abdulğanî Eş-Şehhâbî, Halep Üniversitesi, Yüksek Lisans Tezi, Tarih Bölümü, 1998-1999, Yer Numarası: 723.309561

(Osmanl Hâkimiyetinin Başlangıcından 16. Asra Kadar Mekke-i Mükerreme 1517-1591) Hazırlayan: İbtisâm bint Muhammed Sâlih bin Abdurrahmân Keşmîrî, Danışman: Dr. Yusuf bin Ali bin Râbi es-Sekafi, Ümmü’lKura Üniversitesi, Doktora Tezi, Yakınçağ Tarihi, 2001, Yer Numarası: 956.08

63- جمعية الاتحاد والترقى اثرها فى قيام الثورة العربية الكبرى (İttihat ve Terakki Cemiyeti ve Büyük Arap İsyanı’na Etkileri) Hazırlayan: 'Ahud Muhammed El-Hırşa, Danışman: Muhammed Salim Et-Taravne, Mute Üniversitesi, Yüksek Lisans Tezi, 2004, Yer Numarası: 956.084

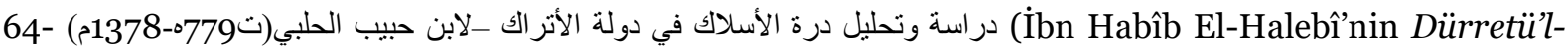
Eslâk fi Devleti'l-Etrâk İsimli Eserinin Tahlil ve İncelemesi) Hazırlayan: Ali er-Rıâ el-Kâdirî, Danışman: Ammâr Muhammed En-Nehâr, Dimeşk Üniversitesi, Yüksek Lisans Tezi, Yakın Çağ ve Çağdaş Arap Tarihi, Yer Numarası: 956.0546

65 -2003 الحملة الفرنسية على مصر و الثام: دراسة ومقارنة بين المؤرخ العربي الجبرني والمؤرخ التركي عزت الدارندلي- Fransa'nın Mısır'a ve Şâm’a Saldırısı: Arap Tarihçi El-Cebrânî ve Türk Tarihçi İzzet El-Dârendelî’nin Karşılaştırmalı İncelemesi) Hazırlayan: Necât Sâlim Ziyâd Betraş, Danışman: Dr. Muhammed Harb-Dr. Abdurrahman El-Cebrenî, Mute Üniversitesi, Yüksek Lisans Tezi, 2003, Yer Numarası: 962.02.

Mimari ile Alakalı Tezler: Mimari alanda yapılan tezleri iki kısma ayırmak mümkündür. Bunlardan birincisi Osmanlı ve Türk mimarisinin vasıflarını ve özelliklerini inceleyen tezlerdir. Bunlar Osmanlı döneminde inşa edilen evler, hanlar, saraylar vb. mimari yapıların teknik ve sanatsal yönlerini incelemektedir. İkincisi ise mimari nitelikleri mukayese eden akademik çalışmalardır. Bunlar Osmanlıİran, Osmanlı-Arap, Osmanlı Memlük eserlerinin mimari yönden karşılaştırmasını yapan tezlerdir.

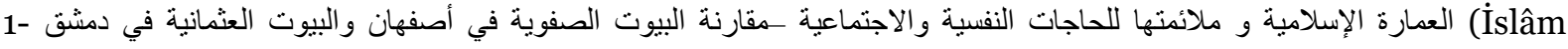
Mimârîsi ve Onun Rûhî-İctimâî İhtiyaçlara Uygunluğu: Isfahan'daki Safevi Evleri ve Şâm'daki Osmanlı Evlerinin Mukâyesesi) Hazırlayan: Sümeyye Ümidvârî, Danışman: Dr. Selvî Mîhâîl-Dr. Hâdî Nedîmî, Dimeşk Üniversitesi, Doktora Tezi, Mimarlık ve Mühendislik Fakültesi, Yer Numarası: 723.309565

2- الخانات و القيساريات في كويسنجق في العصر العثماني (Osmanlı Döneminde Köysancak’ta Hanlar ve Kapalıçarşllar) Hazırlayan: Zeydân Reşîdhan Erdel el-Berdûstî, Danışman: Prof. Dr. Muhammed Şulân Et-Tayyâr, Dimeşk Üniversitesi, Doktora Tezi, Tarih Bölümü, 2011, Yer Numarası: 956.6303 
3-3 المساجد في محافظة إربد خلال العصر العثماني المتأخر:دراسة معمارية مقارنة (Osmanlı'nın Son Dönemlerinde İrbid'deki Camiler: Mimârî Bakımdan Mukâyese) Hazırlayan: Muhammed Sâlih Avdât, Danışman: Dr. Muhammed Hitâmle, Yermûk Üniversitesi, Yüksek Lisans Tezi, İslâmi Eserler, 1999, Yer Numarası: 915.6503

4- الخانات الإسلامية خلال الفترة العثمانية في جنوب الأردن (Osmanlı Döneminde Ürdün’ün Güneyindeki Hanlar) Hazırlayan: İslâm Muhammed Mâcid Ubeydât, Danışman: Dr. Vâil er-Rüşdân, Yermûk Üniversitesi, Yüksek Lisans Tezi, İslâmî Eserler, 1998, Yer Numarası: 915.6503

5- (16. Ve 17. Asırlarda Şâm'da Osmanlı Tekkeleri: Mimârî ve Sanatsal Açıdan) Hazırlayan: Ahmed Sâlih El-Şiyâb, Danışman: Dr. Vâil el-Rüşdân, Yermûk Üniversitesi, Arkeoloji ve Antropoloji, 2001, Yer Numarası: 915.6103

6- تحصينات مدينة الجز ائر في العهد العثماني (Osmanlı Döneminde Cezayir’in Surları) Hazırlayan: Fazîlet Hamzâvî, Danışman: Prof. Dr. Sâlih Hâlid Sârâ, Yermûk Üniversitesi, Arkeoloji ve Antropoloji Bölümü, 2006, Yer Numarası: 728.810956

(Illk Osmanlı Döneminde Eski Trablus'ta (Libya) Kubeybât Mescitleri 1551-1711) Hazırlayan: Adil El-Mebrûk el-Muhtâr El-Fâr, Danışman: Prof. Dr. Sâlih Sârâ, Yermûk Üniversitesi, Yüksek Lisans Tezi, İslâmî Eserler, 2001, Yer Numarası: 916.1203

8- الثأثير والثأثر الثنبادل بين العمارة العربية والعمارة التركية في الأردن في أواخر الفترة العثمانية (Osmanlı'nın Son Dönemlerinde Ürdün'deki Arap ve Türk Mimârî Yapılarının Karşllıklı Etkileşimi 1864-1918) Hazırlayan: Sâmir Muhammed Cebbârât, Danışman: Dr. Yahyâ Yusuf Zabî, Ürdün Üniversitesi, Yüksek Lisans Tezi, Mimarlık, Yer Numarası: 720.9565

9- الحمّامات الجزائرية من العصور الإسلامية إلى نهاية العهد العثماني (İslâmiyet Asrından Osmanlı’nın Son Dönemine Kadar Cezayir Hamamları) Hazırlayan: Musâvî Arabiyye Selîme, Danışman: Dr. Larec Abdulaziz, Cezayir Üniversitesi, Yüksek Lisans Tezi, Arkeoloji, 1990-1991, Yer Numarası: 725.730965

10- قصور مدينة الجزائر في أواخر العهد العثماني (دراسة أثرية معمارية) (Osmanlı'nın Son Döneminde Cezayir'deki Saraylar: Mimârî Yönden) Hazırlayan: Muhammed Tayyib İkâb, Danışman: Dr. Reşîd Berûbiyye, Cezayir Üniversitesi, İslâmî Eserler, 1994-1995, Yer Numarası: 723.30965

(Eski Nablus Şehrindeki Osmanlı Saraylarında Mimârî Süslemecilik: Bir İnceleme) Hazırlayan: Hünâdî Semîr Nâmık Kenan, Danışman: Dr. Haysem er-Retrout, el-Necâhu'l-Vataniyye Üniversitesi, Yüksek Lisans Tezi, Mimarlık, 2010, Yer Numarası: 728.82095608

1655-1807 Nablus Şeriye Sicilleri Üzerinden Osmanlı Mimârisi Üzerine Bir Okuma) Hazırlayan: Sâire Reşîd Hüsnâ Baliybek, Danışman: Dr. Haysem er-Retrût-Dr. Emîn Ebû Bekr, el-Necâhu'l-Vataniyye Üniversitesi, Yüksek Lisans Tezi, Mimarlık, 2010, Yer Numarası: 720.956082

(Osmanlı Döneminde Filistin'de Meskenlerin Mimârî Tarzının Tahlîli: Nablus) Hazırlayan: Târık Dâvud Ahmed, Danışman: Dr. Hayrî Mer'â, en-Necâhu'l-Vataniyye, Mimarlık, 2008, Yer Numarası: 728.095608 
14- الزخارف الحجرية العثمانية على سور القس (Kudüs Sûrlarındaki Osmanlı Taş Süslemeleri) Hazırlayan: Hâşim Sâlih Muhsin, Danışman: Dr. Yusuf Saîd en-Netşe, Kudüs Üniversitesi, Yüksek Lisans Tezi, İslâmî Eserler, 2002, Yer Numarasi: 723.30956421

15- صناعة الزجاج في مدينة الخليل :الفترتين المملوكية و العثمانية (Osmanlı ve Memlûk Dönemlerinde El-Halil Şehrinde Cam Sanatı) Hazırlayan: Muhammed Mustafa Câbir İsmail, Danışman: Dr. Nazmî el-Cu', Kudüs Üniversitesi, Yüksek Lisans Tezi, İslâmî Eserler, 2000, Yer Numarası: 748.2956471

15- التطور المعماري في حارة باب الناظر في القس في العصرين المملوكي والعثماني :دراسة أثرية وتاريخية ومعمارية (Memlûkler ve Osmanlılar Döneminde Kudüs'te Babu'n-Nâzir Bölgesinin Mimârî Gelişimi: Eser, Tarih, Mimârî) Hazırlayan: Emel Ekrem Ebu'l-Hevâ, Danışman: Dr. Yusuf Saîd en-Netşe, Kudüs Üniversitesi, Yer Numarası: 923.30956421

16- الإضاءة الطبيعية في العمارة الإسلامية: دراسة ميدانية مقارنة في قاعات بعض المنازل المملوكية والعثمانية بالقاهرة (İslâm Mimârîsinde Tabiî Aydınlatma: Kahire'deki Bazı Osmanlı ve Memlûk Evlerinin Avlulularının Mukâyesesi) Hazırlayan: Mustafa Kemâl Sabri, Danışman: Prof. Dr. Ahmed Abdulmuta el-Celâlî-Prof. Dr. Âdil Yes Muhammed, 'Aynü’ş-Şems Üniversitesi, Yüksek Lisans Tezi, Mühendislik, Yer Numarası: 723.3

17 -1İlâm Yapısında Mimârî Yorumlama ve Yapılandırma: Osmanlı Mısırı’ndaki Örneklerin Tahlili) Hazırlayan: Hâzım Muhammed Nûr Afîfî, Danışman: Dr. İmâm Selbî Fuâd Nassâr, 'Aynü’ş-Şems Üniversitesi, Yüksek Lisans Tezi, Mimarlık, Yer Numarası: 723.30962

18 - التاريخ العمراني لدمق خلال الحكم العثماني(1516-19smanlı Yönetimi Altında Şam’’n Kentsel Gelişim Tarihi 1516-1918) Hazırlayan: Lütfî Fuad Lütfî, Danışman: Prof. Dr. Muhmûd Ali Âmir, Dimeşk Üniversitesi, Yüksek Lisans Tezi, Yakın Çağ ve Çağdaş Arap Tarihi, 2008, Yer Numarası: 956.082

19- الخانات العثمانية في سوريا و المحافظة على الهوية المعمارية(در اسة تحليلية_مقارنة لخانات دمثق -حلب_اللاذفقية) (Suriye'de Osmanl Hanları ve Bunların Mimârî Yapılarının Korunması: Şam-Halep-Lazkiye'de Bulunan Hanların Mukâyesesi) Hazırlayan: Anît Nebye Taama, Danışman: Dr. Abîr Arkâvî, Dimeşk Üniversitesi, Yüksek Lisans Tezi, Mimarlık Fakültesi, 2009-2010, Yer Numarası: 720.956082

20 البيوت العربية في مدينة دمشق في الفترة العثمانية: دراسة تحليلية وفنية ومعمارية (Osmanlı Döneminde Şâm'daki Arap Evleri: Sanatsal ve Mimârî Bakımdan Tahlîl) Hazırlayan: Kâsım Mesud El-Mâzî, Danışman: Dr. Esâme Ebû Kûre, Ürdün Üniversitesi, Yüksek Lisans Tezi, Arkeoloji, 1995, Yer Numarası: 915.6103

21 بsmanlı Camilerinde Dâhilî Yapısal Boşluk: Mimâr Sinân Camileri) Hazırlayan: Nâsır Sâbit Ahmed Mağrîbî el-Hüsnâ, Danışman: Prof. Dr. Ahmed Ez-Zabî, Ulûmu'l-İslâmiyyetü'l-Âlemiyye Üniversitesi, Yüksek Lisans Tezi, İç Dekorasyon, 2011, Yer Numarası: 726.2095608

22- المنشآت المائية لخدمة مكة المكرمة والمشاعر المقسة في العصر العثماني (Osmanlı Döneminde Mekke ve Mukaddes Yerlerin Hizmeti İçin Kurulan Su Tesisleri) Hazırlayan: Âdil Muhammed Abdullah Ğabâşi, Danışman: Prof. Dr. Abdulmenâm Abd, Ümmü'l-Kura Üniversitesi, Doktora Tezi, İslâm Medeniyeti, 1990, Yer Numarasi: 956.08 
Edebiyat ile Alakalı Tezler: Edebiyatla ilgili olarak yapılan akademik çalışmalardan en çok dikkatimizi çeken Yermûk Üniversitesi'nde Feylosof Rıza Tevfik hakkında yapılan tezdir. Bunun haricinde Osmanlı toplumunda şiir, Cezayir'de sûfî şiir vb. konularda da çalışmalar yapılmıştır.

1- وصف الطبيعة عند شعراء بلاد الثام في العصر العثماني حتى منتصف القرن الثالث عثر الهجري : دراسة تحليلية (Osmanll Döneminden Hicrî On Üçüncü Asra Kadar Bilâdü’ş-Şâm Şairlerinin Doğa Tasvirleri) Hazırlayan: Enes Ahmed Kenâkîrî, Danışman: Prof. Dr. Mahmûd Sâlim Muhammed, Dimeşk Üniversitesi, Doktora Tezi, Arap Dili Bölümü, 2006-2008, Yer Numarası: 811.06

2- رضا توفيق حياته نثاطه فى شرق الاردن (Rıza Tevfik: Hayatı ve Ürdün'deki Faaliyetleri) Hazırlayan: İfaf Mahmud Kasım El-Kasım, Danışman: Prof. Dr. Muhammed Recai Ruban, Yermûk Üniversitesi, Tarih Bölüm, 1995, Yer Numarası: 320.9565.

3-3 القس في أدب الرحلات العربية المشرقية في العصر العثماني (Osmanlı Döneminde Ortadoğu Seyahatnâmelerinde Kudüs) Hazırlayan: Esma Câdullah Süleyman Sâlim, Danışman: Dr. Yasin Âyiş Halîl, Ürdün Üniversitesi, Yüksek Lisans Tezi, Arap Dili ve Edebiyatı, 2013, Yer Numarası: 810.93256421

4ürk İşgalinden Önce ve Sonra İskenderiye Edebiyatçlları 1918-1980) Hazırlayan: Afîf Halîl Sukayrak, Danışman: Prof. Dr. İskender Cemîl Loksâ, Kaddîs Yusuf Üniversitesi, Arap Dili, Yer Numarası: 810.909561

5- الثعر في بلاد الثام في العصر العثماني(Osmanlı Döneminde Bilâdü’Ş-Şâm’da Şiir 1516-1798) Hazırlayan: Halîl Kâsım Ğarîrî, Danışman: Dr. Ömer Mûsa Başa,Yer Numarası: 811.856109

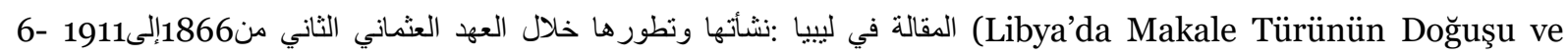
Gelişimi (1866-1911) Hazırlayan: Ahmed Umrân bin Selîm, Danışman: Dr. Muhammed el-Mehdi elĞazâlî, Karbons/Bingazi Üniversitesi, Yüksek Lisans Tezi, Yer Numarası: 814.861209

7- الثعر الصوفي في الجزائر في العهد العثماني : دراسة موضوعية وفنية (Osmanlı Döneminde Cezâyir'de Sûfî Şiir: Konu ve Sanat Yönünden İnceleme) Hazırlayan: Muhtâr Hibâr, Danışman: Dr. Muhammed Abdulmuttalib-Dr. Abduşşâfî Eş-Şûrî, ‘Aynü’ş-Şems Üniversitesi, Arap Dili ve Edebiyatı, 1991, Yer Numarası: 811.05

8- الثعر الاجتماعي في العصر العثماني"دراسة فنية (Osmanlı'da Toplumsal Şiir: Sanat Bakımından İnceleme) Hazırlayan: Semîh Hâc Halîl, Danışman: Dr. Mahmûd Sâlim Muhammed, Dimeşk Üniversitesi, Doktora Tezi, Edebiyat Fakültesi, 2007-2008, Yer Numarası: 811.09

9-9 الثعر الاجتماعي في العصر العثماني: دراسة فنية (Osmanlı Döneminde Toplumsal Şiir: Sanat Bakımından Bir İnceleme) Hazırlayan: Miyâde Tuncî, Danışman: Dr. Ömer Dekâk, Dimeşk Üniversitesi, Doktora Tezi, 2008, Arap Dili Bölümü, Yer Numarası: 811.09

الموشحات المشرقية وأثر الأندلس فيها منذ العصر الأيوبي وحتى نهاية العصر العثماني-10 (Eyyûbîler Devrinden Osmanlların Son Dönemine Kadar Doğu Muvaşşahâtları ve Endülüs Etkisi) Hazırlayan: Mecd el-Efendî, Danışman: Dr. İsâm Kasapçî, Doktora Tezi, Halep Üniversitesi, Edebiyat Fakültesi, 1990, Yer Numarası: 811. 74109

11- الأدب الثعبي في العصرين المملوكي والعثماني(قضاياه ودلالاته الفنبة في ضوء نظرية الادب و النقا) (Osmanlı ve Memlûk Dönemlerinde Halk Edebiyatı: Edebî ve Tenkîd Nazariyeleri Işı̆̆ında Meseleler ve Sanatsal Çağrışımları) Hazırlayan: Feryâl Haydar Âkil, Danışman: Prof. Dr. Cevdet İbrahim- Dr. Abdullatif 
Umrân, el-Baas Üniversitesi, Doktora Tezi, Arap Dili ve Edebiyatı Bölümü, 2005, Yer Numarası: 810.9076

\section{Sonuç}

Osmanlı sonrası dönemde Osmanlı ile alakalı olarak Arap dünyasında yapılmış akademik çalışmalar bize Arap akademisyenlerin Osmanlı ve Türklere karşı nasıl bir bakış açısıyla baktıklarını göstermesi açısından büyük önem arz etmektedir. Yazılan bu tezlerin içerikleri gibi isimleri de bize hangi bakış açısıyla hazırlandıkları hakkında bilgi vermektedir.

İncelemiş olduğumuz tezler yapılmış oldukları ülkelere ve hocalara göre farklılıklar arz etmektedir. Bu farklılıkların temelinde onların Osmanlı'ya ve Türkiye'ye bakış açıları yatar. Bir kısım tezler tarihi ve kültürel birikim üzerinde dururken bir kısmı daha çok siyasi konulara yönelir ve Osmanlı kimliği üzerine eleştirilerde bulunur. Örneğin Suriye ve Filistin'de yapılan tezler daha çok Osmanlı tarihi, Osmanlı siyasi faaliyetlerinin bu bölgeye yansıması ve mimari üzerinedir. Ancak Ürdün'de yapılan tezlerin büyük bir kısmıysa Türkiye ve Türkiye'nin Ortadoğu siyasetiyle alakalıdır. Ürdün'deki tezlerin siyasi alana yoğunlaşmasında Ürdün'ün siyasi geçmişinin büyük etkisi vardır. Ürdün Haşimi Krallı̆̆ı, Arap İsyanı'nın mimarı olan Şerif Hüseyin oğlu Abdullah tarafından kurulmuş olup halen daha bu aile tarafından yönetilmektedir. Böyle olunca mevcut yönetimin geçmişe dair korkuları ortaya çıkmakta ve geçmişinin yeniden tezahür edeceği düşünceleri hakim olmaktadır. Bundan dolayı Türkiye'nin Ortadoğu'ya doğru yapmış olduğu herhangi bir girişim onlar için şüpheli bir tavır olarak algılanmaktadır.

Siyasetle alakalı toplam 26 (yirmi altı) tez yazılmıştır. Bu tezlerin bir kısmını yirminci yüzyıldaki Türkiye Arap devletleri ilişkileri oluşturur. Bu ilişkiler siyasi ve ekonomik yönden ele alınır. İkibinli yıllardan sonra Türkiye'nin Ortadoğu politikası ve bu politikanın dinamikleri de sorgulanır. Bunun haricinde Arap-İsrail sorunu ve bu sorun çerçevesinde Türkiye'nin tutumu, İsrail-Türkiye ilişikleri de üzerinde durulan diğer konulardır. Türkiye'nin dış siyasetini inceleyen tezlerin yanında Türkiye'nin iç siyasi dinamiklerini de ele alırlar. Askerin siyasetteki rolü, iç siyasi gelişmeler, Türkiye-Avrupa Birliği ilişkileri, Kürt meselesi gibi konularda tezlerin üzerinde durduğu meselelerdendir.

Tarihle ilgili 64 (altmış dört) tez yazılmıştır. Yapılan bu tezlerden bazıları Tanzimat ve Islahat Fermanlarının Arap beldelerindeki yansımalarını işler. Bunun haricinde Osmanlı hakimiyeti altında bulunan Arap beldelerinin Osmanlı idaresindeki idari, siyasi, ekonomik durumu da incelenir. Ayrica eğitim tarihi ve hukuk sistemine dair de tezler mevcuttur.

Mimariyla ilgili tezler 22 (yirmi iki) adet olup daha çok Osmanlı döneminden kalma tarihi eserler üzerinedir. Osmanlının yönetimi altındaki Arap beldelerinde bulunan cami, han, kapalıçarşı ev ve benzeri yapılar incelenir. Bu incelemeler mimari yönden olmakla beraber Araplar ve Türklerin karşllıklı etkileşimi ve bunun yansımaları da incelenen konular arasındadır. Bu bağlamda özellikle Cezayir, Mısır, Suriye, Ürdün ve Filistin'deki mimari yapılar dikkatimizi çeker.

Edebiyatla alakalı tezlerin sayısı 11 (on bir)'dir. Bu tezlerde özellikle Osmanlı dönemi şiirinin incelendiğini görmekteyiz. Bunun haricinde Yüzelliliklerden olan Rıza Tevfik’in Ürdün'deki hayıtı hakkında da bir tezin olması ilginçtir. "Türk İşgalinden Önce ve Sonra İskenderiye Edebiyatçıları 19181980" isimli tez ise Arap milliyetçilerinin Osmanlı dönemine bakışını ortaya koyması açısından önemlidir. 
310/ RumeliDE Journal of Language and Literature Studies 2018.11 (April)

The Dissertations on The Ottomans And Turkey in The Library of Jordan University / Y. Beyaz (p. 295-310)

\section{Kaynakça}

Library of Jordan University. 13.08.20017, http://library.ju.edu.jo/EN-library/AboutLibrary.aspx.

Ermiş, H. Ürdün Üniversitesi Kütüphanesinde Bulunan Arap Dili ve Edebiyatı Tezleri. Sakarya Üniversitesi İlahiyat Fakültesi Dergisi, (19), s. 219-220. 